\title{
Growth, Survival and Proximate Body Composition of M. dayanum Larvae Fed Artificial Food and Natural Food Organisms under Laboratory Conditions
}

\author{
*Seema Langer, **Yahya Bakhtiyar, Nazia Malik and S. K. Karlopia \\ Department of Zoology, University of Jammu, Jammu-1800 06, India.
}

\begin{abstract}
The present investigation was carried out to study the effect of different live feed and dry feed on growth and survival of $M$. dayanum. The studies were conducted indoor in the plastic water troughs containing newly hatched larvae of Macrobrachium dayanum (hatched in laboratory from the brooders collected from Gho-Manhasa stream) were stocked at a density of 20 prawn larvae per trough having 10 litres of water. The increase in weights and lengths were used as measures of growth. The duration of the experiment was 45 days. Seven dietary treatments tested were viz., Artificial diet with 45\% Protein (LFd1), Rotifers like Asplanchna and Brachionus (LFd2), Wild Zooplankton (LFd3), Bioenriched zooplanktons (raised on Chlorella, cod liver oil and vitamin C) (LFd4), Artemia (LFd5), Chironomus (LFd6), Oligochaetes (LFd7). Among different treatments it was observed that higher weight gain of the larvae of $M$. dayanum was attained on diet LFd7 $(11.08 \pm 0.11 \mathrm{mg})$. The weight gain recorded was highest for diet LFD7 followed by other diets as $\mathrm{LFd} 7>\mathrm{LFd} 5>\mathrm{LFd} 6>\mathrm{LFd} 4>\mathrm{LFd} 3>\mathrm{LFd} 2>\mathrm{LFd} 1$. The survival percentage also showed a significant $(\mathrm{P}<0.05)$ variation during the present investigation. The maximum survival was recorded for LFd7 $(98.33 \pm 2.88 \%)$. Protein content of the prawn after the treatment was found to be highest for LFd7 followed by LFd4.
\end{abstract}

Key words: Macrobrachium dayanum, Growth, Survival, Food organisms, Jammu 


\section{Introduction}

In nature, fish and prawn larvae during their "critical phase" receive nourishment by selectively feeding upon phytoplankton and zooplankton available in their habitat. Such a diet not only provides wide spectrum composition of food but also because of its autodigestion characteristics, facilitates a better assimilation in larvae. In intensive rearing of larvae of fishes and prawns, feeding constitutes a major factor since they obtain their entire nutritional requirement (except part of mineral requirement) through the food they consume (Pillay, 1990). The normal behaviour and growth of larvae mainly depends upon the quality of the diet provided to them. However, some formulated feeds have been observed to be richer in protein than live feeds but appraisal of literature reveals that larvae prefer live feed to formulated feeds. Moreover, the minerals and micronutrients needed by early stages of fish, prawn and shrimp are not yet fully understood and hence cannot be incorporated in formulated feeds. On the other hand, the natural live food organisms supply all these micronutrients which otherwise are not known to us. Since live feed is rich in proteins, carbohydrates and fats along with various types of vitamins and minerals, therefore it is always preferable to have a regular supply of live feed (Singh et al., 1994). Further still, many scientists have advocated that after hatching, for a short period of time, during their "critical period", the spawn do not take artificial feed but subsist on natural food (Jhingran, 1991). Thus "live feed" serves as "living capsules" of nutrition (Tiwari, 1986). The nutritional quality of live feed can be further enhanced by using technique known as "bioenrichment" so that nutritional status of the fishes, prawns and shrimps feeding on them could be increased. "Nutritional death" in fishes, shrimps and prawns, therefore, can be minimized by providing them "live feed" as and when required (Singh et al., 1994). The present study was conducted to study the effect of different feed on the growth and survival of $M$. dayanum larvae so as to provide beneficial information regarding the culture of this freshwater prawn in aquahatcheries.

\section{Materials and Methods}

\section{Rearing units and Procedure}

The study was conducted at the Wet Lab, Department of Zoology, University of Jammu. Newly hatched larvae of $M$. dayanum (hatched in laboratory from the brooders collected from Gho-Manhasa stream) were stocked at a density of 20 prawn larvae per trough having 10 litres of water. Water in the troughs was changed every alternate day. In each of the container, small pieces of PVC pipes and small pebbles were placed so as to provide refuge for prawns and help prevent cannibalism. The increase in weights and lengths were used as measures for growth. The duration of the experiment was 45 days.

\section{Feeds and feeding rates}

Seven dietary treatments tested were:

(1) Artificial diet with $45 \%$ Protein (LFd1)

(2) Rotifers like Asplanchna and Brachionus (LFd2) 
(3) Wild Zooplankton (LFd3)

(4) Bioenriched zooplanktons (raised on Chlorella, cod liver oil and vitamin C) (LFd4)

(5) Artemia (LFd5)

(6) Chironomus (LFd6)

(7) Oligochaetes (LFd7)

Three replicate troughs were assigned to each treatment. The prepared artificial feed was formulated to contain $45 \%$ protein and processed into small pieces. The ingredient composition of the formulated feed was similar to that of the composition used in previous experiment. The Chironomous, oligochaete and zooplankton were selected based on previous studies on food preferences in nature.

Artificial feed was provided at a rate of $10 \%$ body weight of prawns $(5 \%$ in the morning and 5\% in the evening), while live feed was provided ad-libitum. Prawns in each tank were weighed weekly to nearest $0.1 \mathrm{mg}$ and counted for determination of average weight and survival.

\section{Results and discussion}

As is evident from Table 1, analysis of variance (ANOVA) on culture time (45 days) was significant $(\mathrm{P} \leq 0.05)$ for all seven treatments. It was seen that higher weight gain of the larvae of $M$. dayanum was attained on diet LFd7 $(11.08 \pm 0.11 \mathrm{mg})$ followed by other diets as $\mathrm{LFd} 7>\mathrm{LFd} 5>\mathrm{LFd} 6>\mathrm{LFd} 4>\mathrm{LFd} 3>\mathrm{LFd} 2>\mathrm{LFd} 1$.However, the weight gain recorded for diet LFd5 $(10.86 \pm 0.04 \mathrm{mg})$ did not differ significantly $(\mathrm{P}>0.05)$ from LFd7. The weight gain recorded for diet LFd5 (10.86 \pm 0.04$)$ did not differ significantly from LFd4 $(10.68 \pm 0.15 \mathrm{mg})$ and LFd6 $(10.73 \pm 0.13)$. The weight gain recorded for $\mathrm{LFd} 3(10.44 \pm 0.12)$ and $\mathrm{LFd} 2(10.27 \pm 0.26)$ did not differ significantly from each other. The values recorded for artificial diet LFd1 $(9.47 \pm 0.07 \mathrm{mg})$ differed significantly from other six treatments.

Percentage weight gain followed the similar trend as weight gain. The value of \%SGR was recorded to be highest for LFd7 $(2.59 \pm 0.01)$ followed by LFd5 (2.55 \pm 0.01$), \quad$ LFd6 (2.53 \pm 0.02$), \quad$ LFd4 (2.52 \pm 0.03$), \quad$ LFd3 $(2.49 \pm 0.02), \quad$ LFd2 $(2.48 \pm 0.05)$ and $\operatorname{LFd} 1(2.35 \pm 0.11)$.

The survival percentage also showed a significant $(\mathrm{P}<0.05)$ variation during the present investigation. The maximum survival was recorded for LFd7 $(98.33 \pm 2.88 \%)$ followed by LFd6 $(95 \pm 0.00), \quad$ LFd5 $(95 \pm 0.00), \quad$ LFd2 $(93.33 \pm 2.88), \quad \mathrm{LFd} 4$ (91.66 \pm 2.88$), \mathrm{LFd} 3(88.33 \pm 2.88 \%)$ and LFd1 $(75.0 \pm 5.0 \%)$. The values recorded for LFd7, LFd6 and LFd5 and LFd2 did not differ significantly ( $\mathrm{P}>0.05)$.

The body composition of the flesh of prawn at the end of experiment treated with seven different diets was estimated in terms of moisture, protein, lipid and ash content (Table-2). The gross composition of prawns was observed to be significantly $(\mathrm{P}<0.05)$ influenced by the dietary treatments. The moisture content was recorded highest in LFd1 $(80.18 \% \pm 0.12)$ followed by LFd2 $(80.10 \pm 0.05)$, LFd5 $(80.02 \pm 0.14)$, LFd3 (79.99 \pm 0.17$)$ LFd6 (79.72 \pm 0.09$),$ LFd4 (79.69 \pm 0.15$)$ and LFd7 (79.65 \pm 0.20$)$. However, the values recorded for LFd1, LFd2, LFd3 and LFd5 did not differ significantly among themselves. 

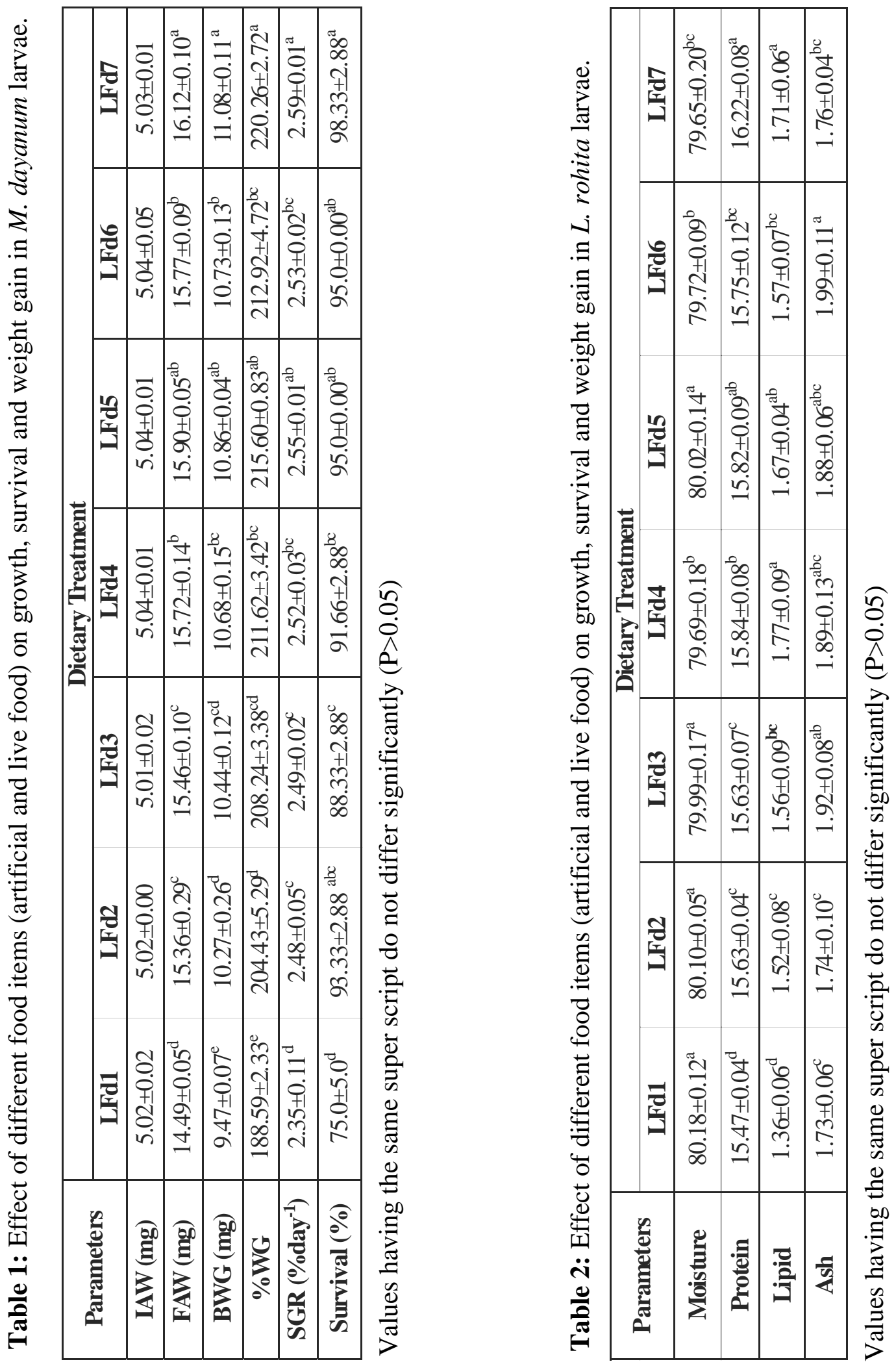
The protein content of the body of animal was recorded to be highest for LFd7 $(16.22 \pm 0.08)$ followed by LFd4 (15.84 \pm 0.08$), \quad$ LFd5 (15.82 \pm 0.09$), \quad$ LFd6 (15.75 \pm 0.12$), \mathrm{LFd} 3$ and LFd2 $(15.63 \pm 0.07$ and $15.63 \pm 0.04)$ and LFd1 $(15.47 \pm 0.04)$. The value recorded for LFd4, LFd5 and LFd6 and also for LFd2 and LFd3 did not differ significantly $(\mathrm{P}>0.05)$ among themselves.

The lipid content of the body of animal was found to be highest for LFd4

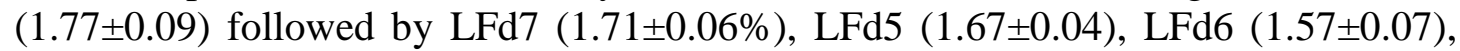
LFd3 (1.56 $\pm 0.09 \%)$, LFd2 $(1.52 \pm 0.08 \%)$ and LFd1 (1.36 $\pm 0.06 \%)$. The highest values recorded for LFd7 did not differ significantly from LFd5 and LFd4.

Ash content in the body of animal was found to be highest for LFd6 $(1.99 \pm 0.11)$ which was not found to be significantly different from LFd3, LFd4 and LFd5, where as for LFd7 the ash content of the body was found to be $1.76 \pm 0.04$. The least content of ash in body of animal was found with diet $1.73 \pm 0.06$ which was not significantly different from LFd2 (1.74 \pm 0.10$)$.

Correlation analysis of four main body constituents of $M$. dayanum indicated that the moisture showed highly significant negative correlation with $(\mathrm{P}<0.01)$ protein $(\mathrm{r}=$ $-0.66, \mathrm{P}<0.01)$, and positive but insignificant correlation with ash $(\mathrm{r}=0.27 \pm \mathrm{P}>0.05)$ whereas lipid showed positive but insignificant correlation with ash $(r=0.303$, $\mathrm{P}>0.05)$.

\section{Discussion}

Prawns in general are known to be opportunistic omnivores and appear to utilize different types of food items efficiently (Tidwell et al., 1997ab). Effect of different live food organisms and artificial feed on growth and survival of prawns has been investigated by several authors (Fujimura, 1966; Ling, 1969; Sick and Beaty, 1975; Ang and Cheah, 1986; Lovett and Felder, 1988; Alam et al., 1993; Jones et al., 1993; Coyle et al., 1996; Kumlu, 1999; Martinez-Farnandez et al., 2006) and all of them came up with the results which were altogether different from one another. During the present study, Artemia (Lfd7) was recorded to be the best food organism for the early stages of $M$. dayanum larvae which was followed by Oligochaetes (LFd5), Chironomids (LFd6), bio-enriched zooplanktons (LFd4), wild zooplankton (LFd3), rotifers (LFd2) and artificial diet (LFd1) with (45\% protein). No significant difference $(\mathrm{P}>0.05)$, was recorded in terms of growth (Body weight gain (BWG) and Specific growth rate (SGR) and survival percentage). Proximate estimation of the flesh of the larvae at the end of experiment also revealed protein levels $(16.22 \pm 0.08 \%)$ to be higher with LFd7 and the value was found to be significantly different from the values recorded for other treatments. Among all the treatments, Crude protein (CP) value was recorded to be lowest with LFd1 $(15.47 \pm 0.04 \%)$. Lipid content was found to be highest in the larvae fed LFd4 and lowest for LFd1. Survival percentage was also recorded to be highest for Artemia and the value however was not found to differ significantly from LFd6, LFd5 and LFd2. The results of the present study are found to be in accordance with previous studies carried out by some investigators who found Artemia as an excellent diet for newly hatched fish (Seale, 1933), Shrimp larvae 
(Hudinaga, 1942), Carassius auratus (Abi-Ayad and Kestemont,1994) and fresh water prawn larvae (New, 1995).

Dhert et al. (1993) developed a simple culture system for the juvenile and adult Artemia as food for post larvae of Penaeus monodon. The growth performance of shrimp reared from PL-4 to PL-5 on juvenile Artemia live prey was identical to the growth obtained while feeding newly hatched with Artemia. Supplementation of HUFA (Highly unsaturated fatty acids) enriched Artemia fransciscana has been stressed by many workers as it has been observed to significantly improve the survival, growth, disease resistance and other environmental stress resistance in shrimp (Leger and Sorgeloos, 1992; Rees et al., 1994; Kyungmin et al., 2000; Immanuel et al., 2004; Immanuel et al., 2007).

The larval stages of prawn (upto stage VI) have been observed to have a poorly developed gut i.e. a small hepatopancreas and a lack of anterior midgut diverticulae (Deru, 1990) which are the main sites for digestive enzyme production in early stages of penaeid shrimp (Lovette and Felder, 1990; Abubakr and Jones, 1992). The larval stages therefore, are unable to readily digest artificial diets during their first feeding period and chiefly rely on live food source which is highly digestible and also provides exogenous prey enzymes (Jones et al., 1993). More specifically, the live food should be zooplankton since $M$. rosenbergii is carnivorous during their first larval stages and thereafter is observed to become more inclined towards omnivory and the capture of food by the larvae is non selective but its ingestion has been documented as a selective process (Barros and Valenti, 1997). Early stages of $M$. rosenbergii are not active hunters despite having a good power of vision (Daniels et al., 1992) they seem to capture food by chance encounter (Moller, 1978). Another reason for superiority of live feed over artificial food might be due to the fact that only live preys move continuously in water column thus ensuring very high chances of encounter and enhance the perception of extra chasing stimulus. On the other hand, artificial feed requires a continous agitation in order to be kept in suspension, and this may damage fragile larvae (Lavens et al., 2000). First feeding stage prawn larvae have been observed to readily ingest newly hatched Artemia nauplii $( \pm 500 \mu \mathrm{m}$ length). However, the cladoceran Moina micrura $( \pm 600 \mu \mathrm{m})$, which may be used as a cheap substitute or supplement for Artemia, is not taken up before some higher stages (Stage IV) and above are reached (Alam et al., 1995). Rotifer Brachionus plicatilis ( \pm $150 \mu \mathrm{m})$, has also been considered to be a good zooplankton starter diet for marine fish and many penaeid shrimp, except for M. rosenbergii (Lovette and Felder, 1988). An explanation for this observation may be that as larva exerts too much in capturing sufficient number of rotifers to meet its nutritional requirements, these eventually results in an unfavourable energy balance. This explanation strengthens the observations made in the present study wherein rotifers resulted in the best survival rates which were insignificantly different $(\mathrm{P}>0.05)$ with that of Artemia but resulted in lower growth rate and body protein composition than the larvae fed on Artemia. Artemia thus has been universally accepted as the most favourable live food source in larval fish rearing although many workers tried daphnids, rotifers etc (Sick and Beaty, 1975; Mohanta, 1997) as prawn food but till now Artemia has not been fully replaced and therefore most of the freshwater prawn hatcheries throughout the world are using 
Artemia as chief prawn diet. Gracia et al. (2008) also while working on the lipid composition of Atlantic cod (Gadus morhua) larvae in response to differently enriched Artemia fransciscana suggested that bio-enriched Artemia resulted in good larva performance. Through future research, efforts have to focus on identification of high protein live feed which is small sized (200-300 $\mu$ ) and relatively more preferred and cheaper than Artemia for $M$. rosenbergii larval feeding.

\section{Acknowledgements}

The authors are thankful to the Head Department of Zoology, University of Jammu for providing the necessary laboratory facilities and DST (Jammu and Kashmir Govt.) for providing financial assistance.

\section{References}

[1] Abi-Ayad, A. and Kestemont, P. (1994). Comparison of the nutritional status of goldfish (Carassius auratus) larvae fed with live, mixed or dry diet. Aquaculture, 128: 163- 176.

[2] Abubakr, B. and Jones, D.A. (1992). Functional morphology and ultra structure of the anterior midgut diverticulae of Penaeus monodon (Fabricius, 1979) larvae. Crustaceana, 62: 142-158.

[3] Alam, M.J., Ang, K.J. and Begum, M. (1995). Replacement of Artemia with Moina micrura in the rearing of freshwater shrimp larvae. Aquaculture International, 3: 243-248.

[4] Alam, M.J., Ang, K.J. and Cheah, S.H. (1993). Use of Moina micrura (Kurz) as an Artemia substitute in the production of Macrobrachium rosenbergii (de Man) post larvae. Aquaculture, 109: 337-349.

[5] Ang, K.J. and Cheah, S.H. (1986). Juvenile production of the Malaysian giant freshwater prawn, Macrobrachium rosenbergii de Man, using a modified static green water system. Proceedings of an International Conference on the Development and Management of Tropical Living Aquatic Resources, 141144.

[6] Barros, H.P. and Valenti, W.C. (1997). Comportamento alimentar docamarão de água doce Macrobrachium rosenbergii (De Man, 1879) (Crustacea, Palaemonidae) durante a fase larval: análise quantitativa. Rev. Bras. Zool., 14, 785-793.

[7] Coyle, S., Najeeullah, J. and Tidwell, J. (1996). A preliminary evaluation of naturally occurring organisms, distiller by-products, and prepared diets as food for juvenile freshwater prawn (Macrobrachium rosenbergii). Journal of Applied Aquaculture, 6:57-66.

[8] Daniels, W.H., D'Abramo, L.R., Parseval, L.D. (1992). Design and management of a closed recirculating "clearwater" hatchery system for freshwater prawns Macrobrachium rosenbergii. J. Shellfish Res., 11, 65-73. 
[9] Deru, J. (1990). Studies on the development and nutrition of the caridean prawn, Macrobrachium rosenbergii (De Man) (Crustacea: Decapoda). Ph.D. thesis. University of Wales, Bangor, UK. pp 306.

[10] Dhert, P., Bombeo, R.B. and Sorgeloos, P. (1993). Use of on-grown Artemia in nursery culturing of the tiger shrimp. Aquaculture International, 1: 170177.

[11] Fujimura, T. (1966). Notes on the development of a practical mass culture technique of the giant freshwater Prawn, M. rosenbergii. Working Pap. IndoPacif. Fish. Coun., 12, IPFC/C-66/WP, 47: 4.

[12] Gracia, A.S., Christopher, C.P. and Brown, J.A. (2008). Gowth and lipid composition of Atlantic Cod (Gadus morhua) larvae in response to differently enriched Artemia fransciscana. Fish Physiology and Biochemistry, 34(1): 7794.

[13] Hudinaga, M. (1942). Reproduction, development and rearing of Penaeus japonicus Bate. Jpn. J. of Zool. 10: 305-393.

[14] Immanuel G., Palavesam A., Sivaram V., Michael Babu M. and Peter Marian, M. (2004). Feeding trashfish Odonus niger lipid enriched A. franciscana on growth, stress resistance and HUFA requirements of Penaeus monodon post larvae. Aquaculture 237: 301-313.

[15] Immanuel, G., Citarasu, T., Sivaram, V., Shankar, S. and Palavesam, A. (2007). Bioencapsulation strategy and highly unsaturated fatty acids (HUFA) enrichment in Artemia franciscana nauplii by using marine trash fish Odonus niger liver oil. African Journal of Biotechnology, 6(17): 2043-2053.

[16] Jhingran, V.G. (1991). Fish and Fisheries of India, $3^{\text {rd }}$ Edition. Hindustan Publishing Corporation (India), Delhi.

[17] Jones, D.A., Kamarudin, S. and Le Vay, L. (1993). The potential for replacement of live feeds in larval culture. J. World Aquac. Soc. 24 (2), 199210.

[18] Kumlu, M. (1999). The use of Nematodes as live feed for larval shrimps. Turkish Journal of Veterinary and Animal Sciences, 23: 401-410.

[19] Kyungmin, H., Geurden, I. and Sorgeloos. (2000). Enrichment strategies for Artemia using emulsions providing different levels of n-3 highly unsaturated fatty acids. Aquaculture. 183 (3-4): 335-347.

[20] Lavens P., Thongrod, S. and Sorgeloos, P. (2000). Larval Prawn Feeds and the Dietary Importance of Artemia. In: New, M.B. and Valenti, W.C. (eds). Freshwater Prawn Culture. Blackwell. Oxford 91-111.

[21] Leger, P.H. and Sorgeloos, P. (1992). Optimized feeding regimes in shrimp hatcheries. In AW Fast and L.J. Lester editors. Culture of Marine Shrimp: principles and practices. Elsevier Scientific Publishing Co., Amsterdam, The Neitherlands; pp. 225-244.

[22] Ling, S.W. (1969). The general biology and development of Macrobrachium rosenbergii. FAO. Fish. Rep., 57: 589-606.

[23] Lovett, D.L. and Felder, D.L. (1988). Evaluation of the rotifer, Brachionus plicatilis as a substitute for Artemia sp. in feeding larvae of Macrobrachium rosenbergii. Aquaculture, 71: 331-338. 
[24] Lovett, D.L. and Felder, D.L. (1990). Ontogenetic change in digestive enzyme activity of larval and postlarval white shrimp Penaeus setiferus (Crustacea, Decapoda, Penaeidae). Biological Bulletin 178, 144-159

[25] Martinez-Fernandez, E., Acosta-Salmon, H. and Southgate, P.C. (2006). The nutritional value of seven species of tropical micro algae for black-lip pearl oyster (Pinctada margaritifera L.) larvae. Aquaculture, 257: 491-503.

[26] Mohanta, K.N. (1997). Formulation of feeds for giant freshwater prawn larvae as alternatives or additions to Artemia salina: A review. Fishing Chimes, 17 (7): 11-12.

[27] Moller, T.H. (1978). Feeding behaviour of larvae and post-larvae of Macrobrachium rosenbergii (De Man) (Crustacea, Palaemonidae). J. Exp. Mar. Biol. Ecol. 35, 251-258.

[28] New, M.B. (1995). Status of freshwater farming: a review. Aquaculture Research,26(1):1-54.

[29] Pillay, T.V.R. (1990). Aquaculture-Principles and Practices. Fishing News Books, London, U.K.

[30] Rees, J.F., Cure, K., Plyatiratitivorakul, P. Sorgeloos, and P. Menasveta, (1994). Highly unsaturated fatty acid requirements of Penaeus monodon post larvae: an experimental approach based on Artemia enrichment. Aquaculture, 122: 193-207.

[31] Seale, A. (1933). The brine shrimp Artemia as satisfactory live food for fishes. Trans. Am. Fish. Soc., 63: 129-130.

[32] Sick, L.V. and Beaty, H. (1975). Development of formula foods designed for Macrobrachium rosenbergii larvae and juvenile shrimp. Proc. World Maricult. Soc., 6: 89-102.

[33] Singh, D. K., Kumar, A. and Reddy, A. K. (1994). Role of live feed in fish and prawn seed production and their culture. In: Fishing Chimes, July: 13-16.

[34] Tidwell, J.H., Coyle, S.D., Sedlacek, J.D., Weston, P.A., Knight, W.L., Hill, S.J. D'Abramo, L.R. and Fuller, M.J. (1997a). Relative prawn production and benthic macroinvertebrate densities in unfed, organically fertilized, and fed pond systems. Aquaculture, 149: 227-242.

[35] Tidwell, J.H., Coyle, S.D., Webster, C.D., Sedlacek, J.D., Weston, P.A., Knight, W.L., Hill Jr., S.J., D’Abramo, L.R., Daniels, W.H. and Filler, M.J. (1997b). Relative prawn production and benthic macro invertebrate densities in unfed, organically fertilized, and fed pond systems. Aquaculture, 149: 227242.

[36] Tiwari, V.K. (1986). Live feed culture, Silver jubilee celebrations. Hi tech Aquaculture, open house, May, 15. 
